\title{
COMMENTARY
}

\section{An Arts Organization Policy Brief on Indigenous Knowledges}

\author{
waaseyaa'sin Christine Sy \\ University of Victoria and Open Space House Committee \\ with \\ Yuxwelupton Qwal'qaxala (Bradley Dick) \\ Open Space House Committee \\ France Trépanier \\ Open Space House Committee \\ Eli Hirtle \\ Open Space House Committee \\ Charles Campbell \\ Open Space House Committee \\ Mark Loria \\ Open Space House Committee
}

Rance Mok

Open Space House Committee

Raj Sen

Open Space House Committee

This policy brief provides an overview of Indigenous knowledges for an arts organization on the Pacific West Coast in Canada. To orient readers, the brief is contextualized within the broader arc of the organization's history of commitments to, departures from, and re-engagement with commitments to decolonization and decolonial practice. It provides a list of additional resources.

Keywords: Indigenous peoples; Indigenous knowledges; arts organization; decolonization; policy brief

\section{Introduction}

Open Space is an artist-run centre located in a heritage building in Victoria, British Columbia, an internationally recognized city which itself grows on the lands and coastal waters of the lək' Founded in 1972, the centre "presents contemporary visual art, music, media arts and more" and "supports experimental artistic practices in all contemporary arts disciplines, acting as a laboratory for engaging arts, artists, and communities" (Open Space 2020). ${ }^{1}$ In the spirit of furthering decolonial practices, the centre recently created an organizational policy on Indigenous knowledges. This policy affirms Open Space's acknowledgement of the significance of Indigenous peoples, territories, and knowledges in the work the 
centre carries out, and it guides the organization in its engagements with Indigenous peoples' knowledges. The policy is supported by a comprehensive brief which is intended to be utilized as an education tool for staff and board members. In an effort to contribute to a broader conversation about decolonization that is occurring in arts organizations and communities, specifically in regard to Indigenous peoples and their knowledges, this paper reproduces this policy brief for increased public access. Open Space's particular history and present commitments are included for context and an "Additional Resources" section is provided.

\section{Open Space, Indigenous Presence, and Decolonization}

In 2011, Open Space began making intentional space for, and being guided by, Indigenous ways of being and knowing. This shift was rooted in the long, yet intermittent, presence of Indigenous contemporary art, artists, and curators at Open Space, going back to 1976. The programming had, at certain times, national resonance. For example, in 1994 Open Space hosted the international conference Mined Cultures: Contemporary Artists \& "Post"-Colonialism in the Commonwealth, with renowned artists such as Abenaki filmmaker Alanis Obomsawin, Cree photographer Joyce Whitebear-Reed, Kwagiutl visual artist David Neel, Métis Blackfoot/ Kainai architect Douglas Cardinal, Blood visual artist Joane Cardinal-Schubert, Salish visual artist Rose Spahan, and Cree-Saulteaux performance artist Margo Kane. The first Indigenous curatorial residency at Open Space took place in 2007 with Mohawk multimedia artist Jackson Two Bears. This was followed by the 2009-2013 curatorial residency with Tahltan artist Peter Morin.

As a result of the leadership and energies of Peter Morin, program coordinator Doug Jarvis, artist and Elder Gerry Ambers, Sarah Hunt, and many others, Open Space began to actively integrate what Morin called "Indigenous ways of knowing" into its core operations and programming. Morin was the catalyst for a major shift in how Open Space imagined its role. An artist and curator of Kanien'kehà:ka and French ancestry, France Trépanier held the third Indigenous curatorial residency from 2014 to 2017. Open Space recognised the importance of engaging with Indigenous communities and building lasting relationships by using methods and protocols that value different voices and perspectives. The curatorial approach focused on creating settings, spaces and moments-multiple entry points through which Indigenous communities could engage with contemporary art on their own terms. This approach was also inspired by the notion of the "ethical space of engagement," developed by Cree scholar Willie Ermine (1993) based on his reflections on Roger Poole's Towards Deep Subjectivity. According to Ermine, "the ethical space is formed when two societies, with disparate worldviews, are poised to engage each other" $(1993,193)$. The concept, when applied as part of a collaborative approach between Western society and institutions and Indigenous peoples, can create new ways of seeing and understanding. Concretely, Open Space's decolonial intentions manifested through culturally relevant programs that brought Indigenous peoples into the gallery space and took the gallery out into Indigenous communities. With a focus on Indigenous youth and Elders, these programs included the "Indigenous Youth Arts Program," the "Red Words Series," and the two-year community-based project "Awakening Memory" (Open Space 2020). Importantly, one of the outcomes of Open Space's decolonial commitments was the creation of a permanent Aboriginal curatorial position, one of the first such position in the artist-run centre network at the time.

Framed as decolonization, these changes also resulted in increased support from external funders through various grants. The Canada Council for the Arts, through the Indigenous Curatorial Residencies Program, supported the presence of Indigenous curators at Open Space from 2009 to 2016. Both the Canada Council for the Arts and the BC Arts Council financially supported the creation of the permanent Indigenous curator's position.

In 2017, the retirement of long-time Executive Director Helen Marzolf launched the search for a new ED. Some artists and board members saw this as an opportunity to "slow down" the decolonial shifts at Open Space and return to an understanding of art practices more aligned with a Western art lens. The hiring of a new ED became a catalyst for different worldviews and positions to collide. This led to the public resignation of the Indigenous curator (Rungh Magazine 2018a). Other staff resignations followed. This situation led to a public boycott of Open Space launched by the Aboriginal Curatorial Collective (Rungh Magazine 2018b). Many artists respected the boycott and cancelled their participation in Open Space programs. Support was expressed on a national level, as these events resonated widely in an arts system still struggling with systemic racism and white supremacy. At the same time, the funders decided to put Open Space on notice until a clear position could be formulated. The board of directors resigned in block and a new interim board was appointed; shortly thereafter, they provided a statement (Rungh Magazine 2018c). Locally, Indigenous, Black, and People of Colour members of the arts community stood up and respectfully engaged in challenging public dialogues around decolonizing process at Open Space and, more broadly, the Canadian art system. These events took the form of talking circles, public forums, and a forgiveness ceremony conducted by two Indigenous knowledge keepers. 
Since spring 2018, Open Space has implemented numerous changes in its operations. It is conscientious about expanding its circle of relations to include those who are engaged in committed practices in/ towards decolonization even as Open Space is actively and reflexively asking what decolonization is. Some of these changes have included, but are not limited to, significantly increasing Indigenous peoples and other racialized peoples in governance and operations. This involves more than just diversifying representation; it also involves engaging with new ideas, knowledges, practices, and histories. It has also included implementing decolonizing processes such as circle conversations in which staff, administration, and directors participate together.

These changes and processes apply to the physical structure of Open Space as well. In response to the need to upgrade the building that houses Open Space, a House Committee was created in April 2020. The committee includes community members France Trépanier, Rance Mok, and Mark Loria; Open Space Indigenous curator Eli Hirtle and Executive Director Raj Sen; and board members Yuxwelupton Qwal'qaxala, waaseyaa'sin Christine Sy, and Charles Campbell. ${ }^{2}$ As part of its mandate, the committee needs to address the core question of upgrading the building and has been thinking through what it means to be decolonizing relationships with place and peoples. This includes not only the arts community but also Indigenous peoples, with a focus on lək'wənən peoples because Open Space's building exists on lək'wəyən lands. Because the diversity of our committee lent itself to highly nuanced conversations, including the sharing of Indigenous knowledges by Indigenous committee members, a process for documenting-or not documenting-knowledges in committee notes was implemented. This situation quickly translated into recognizing the need for a broader organizational policy about Indigenous knowledges, particularly as Open Space is committed to existing, and ideally building new, relationships with Indigenous peoples. The House Committee created a policy brief and draft policy that will guide how Open Space is in relationship with Indigenous peoples and knowledges. The policy has been ratified by the Open Space Board of Directors.

The policy brief aligns well with KULA's special issue on Indigenous Knowledges, and members of the House Committee felt other arts centres who are, or would like to be, working in/towards decolonization might find it helpful. After being reviewed by both Open Space board and staff, what follows is a brief that includes a discussion on the meaning of and discourse around Indigenous knowledges as well as their significance and signification. Since it is a brief, the review of literature on Indigenous knowledges is not exhaustive, but rather covers themes intended to be resonant with existing topics and debates in arts communities. In order to allow interpretative breathing room for readers who may wish to utilize this for their own policy creation, the policy that arises from this brief is not included. It is also important to note that this brief will live in other ways. For example, it will be shortened into an educational document for our partners and the Open Space arts community and may also live on Open Space's website in text or other forms.

\section{Policy Brief: Indigenous Knowledges and Documenting Indigenous Knowledges}

\section{Indigenous Knowledges: Meaning and Discourse}

While the identification of Indigenous knowledges and their signification is relatively recent, there is much written about them and much to discuss and elaborate upon. First, Indigenous knowledges are often denoted in the singular, which suggests that there is one Indigenous knowledge (Manulani Aluli-Meyer, personal communication, June 18, 2010). However, there are many Indigenous nations, communities, and peoples, and there are many different kinds of knowledge that Indigenous peoples produce. As such, Indigenous knowledges is utilized here to signify this plurality and complexity.

Indigenous knowledges may be understood to broadly mean any knowledges that are produced by Indigenous peoples globally. They are also situated in place. Further, as Indigenous peoples travel or migrate by force or choice, Indigenous knowledges are also in transit. Because knowledges are also in transit, they exist outside of their "homes" and germinate elsewhere and in exchange with other Indigenous and non-Indigenous knowledges. They are defined or conceptualized in myriad ways. For instance, Jennifer Wemigwans (2018), whose research examines the production of Indigenous knowledges in digital environments, discerns between two distinct forms: sacred teachings and personal knowledge. She says,

Sacred teachings consist of Traditional Knowledge passed on through ceremonial protocols. Only Elders and Traditional Teachers who have been gifted the Indigenous Knowledge and teaching in this way can share those teachings publicly and transfer them. This type of Indigenous Knowledge is often

\footnotetext{
${ }^{2}$ During the publication process of this paper, Open Space has endured a number of challenges resulting in shifts in committee membership and postponement of this work.
} 
considered as belonging to the community and held in trust by Knowledge Keepers and Elders expected to abide by cultural protocols entrusted to that knowledge.

Personal knowledge is acquired through individual educational pursuits, empirical processes, or the gifts that one is born with or has received through revealed knowledge, which includes spiritual knowledge gained through dreams, visions, intuitions, and meditations. Personal knowledge is not bounded by the cultural protocols of the community in the way that Traditional Knowledge is. An Elder or Traditional Knowledge Keeper also acquires knowledge through empirical observations as well as the gifts that he or she is born with or has received through revealed knowledge. However, the role of an Elder or Traditional Knowledge Keeper is very different from the role of an Indigenous artist or academic who has acquired personal knowledge. Although an Elder might choose to claim that role of an artist, it is highly unlikely that an Indigenous artist or academic or politician would claim the role of an Elder or Traditional Knowledge Keeper unless she or he is acknowledged as one and conferred with the title by the community. This distinction is important because it is a concept understood instinctively by Indigenous communities even though not always articulated or discussed. (Wemigwans 2018, 3-4)

Drawing on a body of Kanien'kéha:ka and Anishinaabe sources, Wemigwans offers a particular baseline for understanding Indigenous knowledges that helps us begin to understand a concept that, while being vital for Indigenous peoples, is elusive for many. While this entry point is useful, it is important to recognize that authority in meaning-making about Indigenous knowledges must be deferred to the Indigenous peoples and communities who are discerning them for their own lives and needs. That is to say, while conceptualizations about Indigenous knowledges may emerge from the intellectual processes of one body of nation-specific scholars, other conceptualizations may look different within the intellectual processes of another Indigenous nation.

Wemigwans also differentiates between Indigenous knowledges and Indigenous information as separate and discernable entities. In a world where Indigenous knowledges are stolen and/or appropriated en masse, teaching people to read for Indigenous knowledges is important. Focussing on an online environment, Wemigwans (2020) contrasts "Indigenous knowledges" with "Indigenous information," stating that the latter does not necessarily come from a recognized knowledge holder or practitioner, a community, or in accordance with protocol. Information may be knowledge that has undergone a process of decontextualization or disembodiment. Stated another way, Indigenous knowledges include embodiment and embeddedness in relationships. Importantly, the sharing of Indigenous knowledges may include a genealogy or relationality of that knowledge. For instance, ceremonialists, singers, or drummers often share from whom they learned a song. Protocols associated with their transmission will be articulated (Wemigwans 2020). From an Indigenous point of view, particular kinds of knowledges may be alive and/or have a spirit unto themselves.

As a phrase, Indigenous knowledges is often utilized interchangeably with local knowledges, traditional knowledges, and traditional ecological knowledges. Local knowledges refers to, in part, the knowledges of Indigenous peoples in a particular "local" place. However, local knowledges is a broad term and may actually refer to the local knowledges of any person or group of people who have been in a place for a period of time long enough to accumulate knowledge. For instance, non-Indigenous farmers, hunters, or fisher people may have decades or generations of knowledges about the ecologies of the places they farm, hunt, or fish in. These places in which non-Indigenous peoples have accrued certain kinds of knowledges may simultaneously be places from which Indigenous peoples have been removed or displaced. Or, if they continue to live in these places, they may have been alienated from their land- and water-based practices and thus the ecological and seasonal knowledges that structure these practices. Further, people without shelter or homes living in downtown urban areas and sex workers will also have "local" knowledges that are highly specialized to place. For this reason, while local knowledges is popularly used interchangeably with Indigenous knowledges, it is helpful to know how they are different. It is also important to discern between Indigenous knowledges, local knowledges, and local Indigenous knowledges, the latter of which refers to the knowledges of the Indigenous peoples in whose homelands and territories one is. Open Space's building and operations are in lək'wəyən peoples' homelands and thus are in relationship with lək'wəəən peoples' knowledges as well as the knowledges of urban and international Indigenous peoples.

Traditional knowledges and traditional ecological knowledges are also widely discussed and discerned in myriad ways. The World Intellectual Property Organization (n.d.) defines traditional knowledges as "knowledge, know-how, skills and practices that are developed, sustained and passed on from generation to generation within a community, often forming part of its cultural or spiritual identity." Traditional ecological 
knowledge, popularly known as TEK, emerged as a concept in the 1980s and refers to "experience acquired over thousands of years of direct human contact with the environment" (Fikret Berkes 1993, 1). Anishinaabe scholar Deborah McGregor discerns between Indigenous views of traditional ecological knowledges, which reflect an Indigenous understanding of relationships to Creation, and "the dominant Eurocentric view of TEK, which reflects colonial attitudes toward Aboriginal people and their knowledge" $(2004,386)$. For the purposes of this policy brief, traditional knowledges are ancestral, temporalized knowledges that may be encoded in oral histories and other oral forms, symbols and glyphs, stories, ceremonies, language, songs, material artefacts, art and myriad formations (e.g., petroforms, artificial intelligence, virtual reality media), as well as corporeal practices.

While many people use the phrases traditional knowledges and traditional ecological knowledges, others find these terms problematic because of the meanings inscribed in and implications arising out of the concept of "tradition." Specifically, "tradition" can operate to further entrench settler colonial ideas situating Indigenous peoples in the past, which eliminates Indigenous peoples from the present and the future. Fixing Indigenous peoples' knowledges-and therefore Indigenous peoples-in the past sets up a kind of logic of extinction: if Indigenous peoples are only in the past, then Indigenous peoples are no longer here in the present, and if Indigenous peoples are no longer here in the present, then Indigenous peoples definitely do not exist in the future. Erasing a contemporary Indigenous presence through notions of "tradition" in turn creates an alibi for the historical and ongoing dispossession, illegal settlement or occupation, and theft of Indigenous peoples' territories.

The term traditional also operates problematically to construct Indigenous peoples' knowledges as static, thereby denying the reality and possibility for change, innovation, generation, and regeneration in knowledges and knowledge production. This perception of stasis contributes to the idea that ancestral knowledges are transmitted unchanged through time and place. This may be true and significant for some forms of knowledges and in some cases transmission of knowledges. For instance, this continuity is exhibited through those artists who maintain an ancestral link by reproducing images and material items in the ways their ancestors did. In some cases, this artistry, be it oral or material, is associated with particular families, responsibilities, ceremonial transmission, discipline, and protocols. However, even as such forms and methods of preserving traditional art exist, Indigenous artists and their productions also demonstrate, disrupt, or transcend the complexities of tradition, transgress tradition, or create outside of the paradigm of tradition altogether. There are Indigenous artists such as Elizabeth LaPensée, Amanda Strong, and Lawrence Paul Yuxweluptun, media labs like Aabijijiwan New Media Lab and IM4, as well as project teams, like Jason Edward Lewis and Skawennati Fragnito's Initiative for Indigenous Futures, that utilize various technologies and digital platforms to produce and create new art forms and methods. In many ways, these artists and projects demonstrate Indigenous peoples' orientation with the future and ensure Indigenous peoples' presence in it.

Finally, the idea of "tradition" has been mobilized against and within Indigenous communities in ways that enforce different kinds of structural power, such that only certain people have "tradition" or can have access to it. This structuring of power creates highly specialized conditions with constructed rules around parameters for access. It is absolutely necessary to recognize that Indigenous peoples do have ancestral and newly innovated methods, ceremonies, laws, protocols, or familial practices that determine who does what in terms of certain practices as well as how, when, why, and for whom they do it. However, it is simultaneously necessary to understand that the idea of "tradition" can be and has been mobilized in ways that problematically create systems and dynamics of inequitable power amongst and between Indigenous peoples, families, and communities. This can occur along lines of class that have been created by settler colonial impositions of certain economic and social systems. According to France Trépanier, in the art world, the word traditional has been used, through a Western art lens, to diminish and devalue the importance of Indigenous art, as objects in that frame became either artefact or craft. Before contact with Europeans, Indigenous art was, and still is, a practice embedded in worldviews, cultural protocols, and meaning. It did not neatly reflect the concept of "art" as understood from a Western perspective. Art objects were conduits for transferring knowledge and occupied the full spectrum of practices-sacred and ceremonial, customary and contemporary (France Trépanier, personal communication, July 31, 2020).

These inequities can also occur along lines of gender and sexuality. Indigenous women, gender-non-conforming, non-binary, transgender people, and Two-Spirit folx have noted how tradition is frequently employed to enforce rigid ideas about cultural practices that often perpetuate erasure, isolation, alienation, gatekeeping, control, power-over, and stigmatization for those who are not legible to the status quo or who do not conform to it. Christianity, Victorian values, and settler laws whose primary interests are to protect property-and their heteropatriarchal underpinnings-were historically and continue to be imposed on Indigenous peoples, thereby erasing complexity and diversity in gender, sexuality, relationalities, and kinship ties as well transforming governance structures. These factors are often not considered in modern 
invocations or exaltations of tradition. This lack of consideration can result in reproducing and enforcing gender binaries and heteronormativity across spheres (e.g., ceremony, interpretation of stories).

Complicating this matter even further is the fact that there are hundreds of Indigenous nations in Turtle Island which are distinct. Makings and meanings of gender, practices in sexuality and family orders, and governance cannot necessarily be assumed to be, or not to be, diverse or fluid prior to engagement with Europeans. There are Indigenous peoples who assert that ancestral practices in governance, ceremonial, social and/or family kinship orders cannot be understood through a contemporary lens of gender. In her advocacy for Indigenous women and Two-Spirit people in Indigenous resurgence and nationhood, Métis writer Chelsea Vowel states,

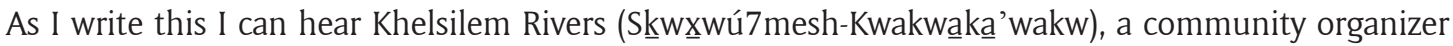
from Vancouver, pointing out that not all Indigenous peoples have the same traditions, and that to avoid perpetuating Pan-Indian stereotypes, we need to have honest discussions about the diversity of our traditions. This is important indeed, as not all Indigenous nations have the same traditions with respect to the fluidity of gender roles. (2014, para. 2)

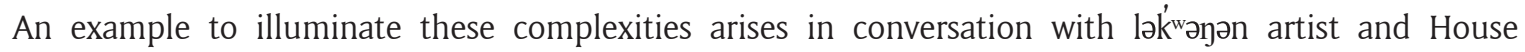
Committee member Yuxwelupton Qwal'qaxala (Bradley Dick), through whom we learn that it is important

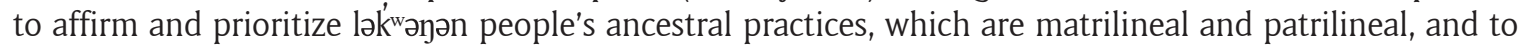
consider the name connected to an individual and their inherent roles and responsibilities to family and community (personal communication, July 18, 2020).

Despite the many problems with the use of traditional in signifying knowledge, it is popularly used, and it resonates widely and deeply for many. It is a term that translates into social and economic capital for many but for Indigenous peoples in particular. The idea of tradition importantly signifies that some Indigenous peoples have survived genocide wrought through settler colonialism. It also affirms that ancestral knowledges persist through the living, ensuring vitality for descendants. Illuminating the problems invoked through the term and idea of traditional is not intended to extinguish or diminish its use. Rather, the intention is to reveal the complexities of its power.

\section{Indigenous Knowledges: Signification and Significance}

Indigenous peoples recognize that knowledges live in and through more-than-human, supernatural, unknown, and unknowable forms. Inuk and Greenlandic artist Laakkuluk Williamson Bathory (2016) conveys this recognition and humility when she says, "the word 'indigenous' means coming from the land. You know, we're not even a half a drop in immensity. We don't even know where the edges of the universe are so how dare we be anything but humble about our humanity." However, colonial, capitalist, scientific, and academic systems of dominance have relegated Indigenous peoples' knowledges in myriad ways such that in certain historical contexts we see Indigenous knowledges being considered primitive, non-existent, expendable, exploitable, fetishized, romanticized, honoured, and essentially used to meet the needs of the dominating society. Through decades of organizing and advocating, Indigenous peoples have obtained some recognition of the significance of their knowledges on their terms vis-à-vis the United Nations Declaration on the Rights of Indigenous Peoples (UNDRIP). On the subject of Indigenous knowledges, article 31 of UNDRIP states,

Indigenous peoples have the right to maintain, control, protect and develop their cultural heritage, traditional knowledge and traditional cultural expression.... They also have the right to maintain, control, protect and develop their intellectual property over such cultural heritage, traditional knowledge, and traditional cultural expressions. (United Nations General Assembly 2007)

Despite this affirmation on an international stage, Indigenous knowledges continue to require being legitimated in a time of modernity, neo-liberalism, and globalization, and this legitimization must in turn be carefully stewarded by Indigenous peoples due to capitalist, scientific, and academic interests in Indigenous knowledges.

With specific reference to Canada, nêyihaw Two-Spirit scholar Alex Wilson (2016) defines epistemicide in relation to Indigenous peoples in Canada as the purposeful settler colonial destruction of Indigenous peoples' knowledges, including the methods through which Indigenous peoples produce, utilize, and transmit their knowledges. Echoing this point about the significance of decolonizing and Indigenous methodologies for Indigenous knowledge production, Māori scholar Linda Tuhiwai Smith (1999), among many others, notes the dominance of Western methods of knowledge production and the settler theft of knowledges 
from Indigenous peoples for the purposes of advancing settler interests, research agendas, and careers. nêhiyaw editor, publisher, and expert on Indigenous copyright Greg Younging elaborates in detail on the ways Indigenous knowledges-or what he refers to as traditional knowledge-have been colonized through Western legal regimes (2018b, 109-36). Further, Mohawk scholar Audra Simpson (2016) argues that the present context of reconciliation in Canada is entangled with colonial interests and as such Indigenous peoples must be critical of how affect (i.e., feeling, emotion) is engaged in ways to create "market" for a new form of assimilation. In this regard, how affect and colonial interests are operating in the building of relationships with Indigenous peoples must always be attended to. It will be important for the members, volunteers, staff, and board of Open Space to engage in a self-reflexive process that considers personal and professional responsibility to ensure mutuality and equity in our relationships with Indigenous peoples, including but

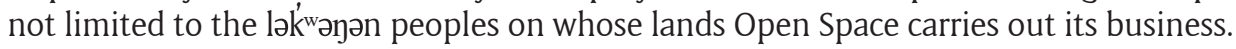

In an effort and commitment to build decolonial and ethical relationships with Indigenous peoples and their knowledges, Open Space will have a policy called "Indigenous Knowledges," which will attend to these points as well as their documentation (i.e., in board meeting minutes, committee notes, community-engaged research). The matter of documentation is both broad and nuanced and will require ongoing discussion, consideration, and policy development. As a matter of Open Space decolonizing relationships with Indigenous peoples, including lək'wəyən peoples, the main principle that will support this policy is that Indigenous peoples' knowledges are their own. Where Open Space members, volunteers, staff, and board members will be influenced by these knowledges as they are transmitted (relationally, orally, through the arts and in other living exchanges), recognition of this source will be paramount, as will care in relationships with these knowledges. Open Space documentation of Indigenous knowledges will occur through processes of consent, recognizing that these processes will require time and labour on the part of Indigenous peoples with whom we work. Younging's (2018a) editorial style guide will serve as a tool in general documentation about Indigenous peoples as well.

\section{Acknowledgements}

We wish to note that Raj Sen passed away suddenly during the time that this article was in review. He is greatly loved and missed.

\section{References}

Berkes, Fikret. 1993. "Traditional Ecological Knowledge in Perspective." In Traditional Ecological Knowledge: Concepts and Cases, edited by Julie T. Englis, 1-9. Ottawa, ON: International Development Research Centre. Canadian Electronic Library/desLibris.

Ermine, Willie. 2007. "The Ethical Space of Engagement." Indigenous Law Journal 6 (1): 193-203. https:// heinonline.org/HOL/P?h=hein.journals/ilj6\&i=193.

McGregor, Deborah. 2004. "Coming Full Circle: Indigenous Knowledge, Environment, and Our Future." American Indian Quarterly 28 (3-4): 385-410. https://www.jstor.org/stable/4138924?seq=1 \#metadata_info_tab_contents.

Open Space. 2020. "Mandate." Accessed July 30, 2020. https://openspace.ca/mandate.

Rungh Magazine. 2018a. "Aboriginal Curator Resigns from Open Space - Rungh Seeks Response." Rungh Magazine, February 20, 2018. https://rungh.org/samachar/aboriginal-curator-resigns-from-open-spacerungh-seeks-response/. Archived at: https://perma.cc/VET3-JLDN.

Rungh Magazine. 2018b. "Call to Boycott Open Space Arts Society." Rungh Magazine, February 25, 2018. https://rungh.org/samachar/call-to-boycott-open-space-arts-society/. Archived at: https://perma. cc/Y766-MN2Q.

Rungh Magazine. 2018c. "Open Space Forms a New Interim Board of Directors; Former Board Resigns." Rungh Magazine, March 13, 2018. https://rungh.org/samachar/open-space-forms-new-interim-boardof-directors-former-board-resigns/. Archived at: https://perma.cc/E37F-TKP4.

Simpson, Audra. "Reconciliation and Its Discontents: Settler Governance in an Age of Sorrow." Lecture, March 15, 2016, University of Saskatchewan, Regina, SK. 1:22:36. https://www.youtube.com/ watch?v=vGl9HkzQsGg.

Smith, Linda Tuhiwai. 1999. Decolonizing Methodologies: Research and Indigenous Peoples. New York: Zed Books.

United Nations General Assembly. 2007. Resolution 61/295. United Nations Declaration on the Rights of Indigenous Peoples. https://www.un.org/esa/socdev/unpfii/documents/DRIPS_en.pdf. Archived at: https://perma.cc/98NH-SAUG.

Vowel, Chelsea. 2014. "Indigenous Women and Two-Spirited People: Our Work Is Decolonization!" GUTS, April 21, 2014. http://gutsmagazine.ca/indigenous-women-two-spirited-people-work-decolonization/. Archived at: https://perma.cc/36WZ-AULH. 
Wemigwans, Jennifer. 2018. A Digital Bundle: Protecting and Promoting Indigenous Knowledge Online. Regina, SK: University of Regina Press.

Wemigwans, Jennifer. 2020. Keynote address at "EMERGENCE: Exploring Indigenous, Decolonizing \& AntiOppression Pedagogies in Virtual Space," hosted by the Canadian Association for the Study of Indigenous Education and the Canadian Critical Pedagogy Association, July 8, 2020.

Williamson Bathory, Laakkuluk. 2016. "This Iqaluit Artist Is Using Her Body to Pull Stereotypes Apart." CBC Arts, December 21, 2016. Video, 4:00, https://www.cbc.ca/arts/exhibitionists/this-iqaluit-artist-is-usingher-body-to-pull-stereotypes-apart-1.3905816. Archived at: https://perma.cc/YST8-7ZW9.

Wilson, Alex. 2016. "Coming into Indigenous Sovereignty: Relationality and Resurgence." Lecture, December 6, 2016, University of Winnipeg, Winnipeg, MB, 51:38. https://www.uwinnipeg.ca/indigenous/weweni/ past-wewenis/coming-in-to-indigenous-sovereignty.html. Archived at: https://perma.cc/NS77-4NX5.

World Intellectual Property Organization. n.d. "Traditional Knowledge." https://www.wipo.int/tk/en/tk/. Archived at: https://perma.cc/BFL7-5ARL.

Younging, Gregory. 2018a. Elements of Indigenous Style: A Guide for Writing by and About Indigenous Peoples. Edmonton, AB: Brush Education.

Younging, Gregory. 2018b. "Appendix D: Gnaritas Nullius (No One's Knowledge): The Essence of Traditional Knowledge and Its Colonization Through Western Legal Regimes." In Elements of Indigenous Style: A Guide for Writing by and About Indigenous Peoples, 109-36. Edmonton, AB: Brush Education.

\section{Additional Resources}

L'Hirondelle Hill, Gabrielle, and Sophie McCall, eds. 2015. The Land We Are: Artists and Writers Unsettle the Politics of Reconciliation. Winnipeg, MB: ARP Books.

Nagam, Julie. 2020. Aaabijijiwan New Media Lab. https://aabijijiwanmedialab.ca/lab. Archived at: https:// perma.cc/JT89-78JD.

Robinson, Dylan. 2020. Hungry Listening: Resonant Theory for Indigenous Sound Studies. Minneapolis, MN: University of Minnesota Press.

Robinson, Dylan, and Keavy Martin, eds. 2016. Arts of Engagement: Taking Aesthetic Action in and Beyond the Truth and Reconciliation Commission of Canada. Waterloo, ON: Wilfrid Laurier Press.

Skawennati, and Jason Lewis. 2021. Initiative for Indigenous Future. https://indigenousfutures.net. Archived at: https://perma.cc/G4YB-FPNM.

Wesley, Saylesh. 2014. "Twin-Spirited Woman: Sts'iyóye smestíyexw slhá:li." TSQ: Transgender Studies Quarterly 1 (3): 338-51. https://doi.org/10.1215/23289252-2685624.

Younging, Greg. 2016. “The Traditional Knowledge-Intellectual Property Interface." In Indigenous Notions of Ownership and Libraries, Archives and Museums, edited by Camille Callison, Loriene Roy, and Gretchen Alice LeCheminant, 67-74. Berlin; Boston, MA: De Gruyter Saur.

How to cite this article: Sy, waaseyaa'sin Christine. 2021. An Arts Organization Policy Brief on Indigenous Knowledges. KULA: Knowledge Creation, Dissemination, and Preservation Studies 5(1). https://doi.org/10.18357/kula.141

Submitted: 20 August 2020 Accepted: 5 November 2020 Published: 22 June 2021

Copyright: @ 2021 The Author(s). This is an open-access article distributed under the terms of the Creative Commons Attribution 4.0 International License (CC-BY 4.0), which permits unrestricted use, distribution, and reproduction in any medium, provided the original author and source are credited. See http:// creativecommons.org/licenses/by/4.0/. 